\title{
REVENUE AUTONOMY OF LOCAL GOVERNMENT: FISCAL DECENTRALIZATION ASPECT
}

\author{
Neringa Slavinskaitė ${ }^{1}$, Romualdas Ginevičius ${ }^{2}$ \\ Department of Economics and Management of Enterprises, Business Management Faculty, \\ Vilnius Gediminas Technical University, Saulètekio al. 11, LT-10223 Vilnius, Lithuania \\ E-mails: ${ }^{1}$ neringa.slavinskaite@vgtu.lt (corresponding author);2romualdas.ginevicius@vgtu.lt
}

\begin{abstract}
The empriral studies of fiscal decentralization depend critically on the correct measurement of fiscal decentralization. Fiscal decentralization is an important aspect of fiscal institutions in both developing and developed countries. One of the most important aspect of fiscal decentralization is revenue autonomy of local government. In this paper we calculated an index of revenue autonomy for selected Europe countries. The most important indicator is tax autonomy in revenue autonomy of local govenment, which based on the Organisation for Economic Cooperation and Development (OECD) methodology. The empirical results show that, in general, the degree of local government revenue autonomy is higher in developed Europe countries than in most developing Europe countries.
\end{abstract}

Keywords: fiscal decentralization, revenue autonomy, local government, SAW, Europe countries, index.

JEL Classification: H2; H71.

\section{Introduction}

Fiscal decentralization have become an interesting topic until today because studies about fiscal decentralization are not only considered from economic perspective but also from other perspective such as politic, geographic, other subject.

Fiscal decentralization, the devolution of fiscal accountability from the central government to lower tiers of governments, has generated enormous interest in the past two decades. Fiscal decentralisation, in its purest form, presumes that local governmental units are given the autonomy over the provision and financing of public goods and services.

State and local governments in Europe countries have access to various fiscal resources. Discretion over them varies considerably, and so does local government governments power to shape their budget and to determine outcomes like public sector efficiency, equity in access to public services or long-term fiscal sustainability. However, current indicators insufficiently reflect the way state and local budgets are funded. The most frequently used indicator is the ratio of local govenment to total tax revenue or spending, which is a poor measure for assessing the true autonomy local government enjoy. Since the power over fiscal revenue is a critical determinant for government finance, a set of more refined indicators for assessing revenue autonomy should be developed.
The development of economic theory on fiscal decentralisation goes back to Tiebout (1956) and since this pioneering work, much theoretical progress has been made, as recently surveyed by Oates $(1996,2005,2008)$. Many challenging questions on fiscal decentralisation, however, remain despite the theoretical progress. Another reason why empirical studies on fiscal decentralisation are so difficult is due to its unclear definition. In empirical studies on fiscal decentralisation, the shares local government revenue or expenditure are often regarded as the degree of fiscal decentralisation. However, these measures of fiscal decentralisation have been criticised by some researchers since they fail to differentiate between the size and the fiscal decision-making power of local governments. To overcome this problem, the OECD (1999) has developed a concept of "taxing power", which is defined as local tax revenue excluding tax sharing and other types of local taxes for which local governments do not control the tax base and tax rate. We address this issue in detail and discuss how we can evaluate revenue autonomy of local government.

The purpose of this article is to analyse literature and calculate the index of revenue autonomy in selected Europe countries.

To achieve stated object, the following goals have been set:

- To review the literature of fiscal decentralization and choice of criteria of evaluation of local governmet revenue autonomy. 
- To calculate index of local government revenue autonomy with multicriteria decision making method (SAW) in Europe countries.

Research methods: review of scientific literature, multicriteria decision making method, analyse of statistical data.

The paper is organised as follows. The first section gives a brief overview on the concept of fiscal decentralization. In second section present evaluation of local government revenue autonomy. The third section develop the methodology of local government revenue autonomy index. The last section gives empirical research in Europe countries.

\section{Concept of fiscal decentralization}

From historical point of view, the demand of good government and governance generated notion of fiscal decentralization. Actually, fiscal decentralization has became main issue for economist and government for last decades, and later it has been discussed to answer the urge in creating good government and governance across the country in the world.

The concept of fiscal decentralization could be understood in several terms. Understanding the concept depends on the context of using the terminology of fiscal decentralization. Some scholarly concepts has defined a fiscal decentralized system which means that central government delegates authorities and responsibilities or transfer functions to local government regarding to financial aspects. The aspects are how to share responsibilities and revenue sources between central government and sub-national government (provincial and district level). Another aspect is related to decision of the amount of authorities and responsibilities transferred to local government in order determine local expenditure and revenue (Davey 2003). In line with Boschmann (2009) also argue that authorities given to local government is intended to make a proper decision in allocating financial resources.

Furthermore to expand concept of fiscal decentralization, it was explained by Beer-Toth (2009) that fiscal decentralization including three elements namely local expenditure, revenue and budgetary autonomy. Those of elements interacts each other. First, local expenditure autonomy is defined as local government determines own expenditure in terms of public goods and services based on their local community needs. Second, local revenue autonomy means that local government has own authorities and responsibility in making decision related to source of their financial.
Local budgetary autonomy appears when the local government would like to manage degree of revenue with respect to spending level.

Regarding to the explanation above, it could be concluded that in fiscal decentralization there a share of financial functions includes power and responsibility from central government different level administrative unit.

\section{Revenue autonomy of local government}

Reviewing the relevant literature, there are studies that have attempted to quantify the degree of revenue autonomy of local governments (Fossati, Panella 1999; Blankart 2000; Stegarescu 2005). Among them is the most detailed study is the one made by OECD Taxing Powers of State and Local Government, which provided a methodological framework for classification of taxes sharing between central and local government according to the degree of autonomy in their determination.

Since taxing power better reflects the fiscal decision-making power of local governments, it has filled a gap between theoretical and empirical research on fiscal decentralisation. However, there still remain challenging issues to be resolved with regard to the measurement of fiscal decentralisation. One such issue is the definition of tax sharing used by the OECD (1999).

In defining taxing power, local revenue from tax sharing is completely excluded. However, in many developed and developing countries, local governments depend significantly on the revenue from tax sharing between central and local governments.

The concept of "tax autonomy" captures various aspects of freedom local governments have over their own taxes. Recognising this problem, the OECD (1999) developed the concept of "taxing power" by categorising local taxes into five types, as shown in Table 1. According to this definition, a local government's taxing power is defined by the size of its local taxes for which it can control either the tax base or tax rate (type a, b and c). What is left out in this definition is, therefore, "tax sharing" for which central government determines the tax base and tax rate either unilaterally or jointly with local governments (type d). Local taxes for which central government determines the tax base and tax rate are also excluded (type e). Since category "f" or "non allocable" was hardly used, the taxing power universe to be well reflected in this taxonomy. Altogether 13 categories were established to capture the various tax autonomy arrangements in OECD countries. The indicators do not take 
account of which level of government actually collects the tax, as this is not relevant to the concept of tax autonomy.

The OECD's definition of taxing power is viewed by many researchers as a better alternative to the conventional measures of fiscal decentralisation. Criticising empirical studies that use subcentral shares of revenue or expenditure to measure the degree of fiscal decentralisation, Ebel, Yimaz (2003) show that the result of previous studies on the effect of fiscal decentralisation, such as that of Davoodi, Zou (1998), is reversed when instead taxing power is used. Stegarescu (2005) also discusses the problems of using sub-central revenue or expenditure shares as the measure of fiscal decentralisation. He argues that the common spending or revenue shares tend to considerably overestimate the extent of fiscal decentralisation.

Although tax sharing is a system of revenue allocation between the central and local governments used worldwide, the treatment of tax sharing in the taxonomy of local revenue and in measuring fiscal decentralisation is surprisingly simplistic.

Table 1. OECD classification of local taxes (Source: OECD 1999)

\begin{tabular}{l|l}
\hline a.1 & $\begin{array}{l}\text { The local government sets the tax rate and any } \\
\text { tax reliefs }\end{array}$ \\
\hline a.2 & $\begin{array}{l}\text { The local government sets the rate and any } \\
\text { reliefs after consulting central government. }\end{array}$ \\
\hline $\mathbf{b . 1}$ & $\begin{array}{l}\text { The local governmen sets the tax rate with no } \\
\text { bounds set by central government }\end{array}$ \\
\hline $\mathbf{b . 2}$ & $\begin{array}{l}\text { The local government sets the tax rate with } \\
\text { bounds set by central govenment }\end{array}$ \\
\hline c.1 & The local government sets tax allowances \\
\hline c.2 & The local government sets tax credits \\
\hline c.3 & $\begin{array}{l}\text { The local governemnt sets both tax allowances } \\
\text { and tax credits }\end{array}$ \\
\hline d.1 & $\begin{array}{l}\text { Local government determine revenue split of } \\
\text { tax sharing }\end{array}$ \\
\hline d.2 & $\begin{array}{l}\text { Local government have to agree with revenue } \\
\text { split of tax sharing }\end{array}$ \\
\hline d.3 & $\begin{array}{l}\text { Central government determines tax-sharing } \\
\text { arrangement by legislation }\end{array}$ \\
\hline d.4 & $\begin{array}{l}\text { Central goverment determines tax-sharing ar- } \\
\text { rangement annually }\end{array}$ \\
\hline e & $\begin{array}{l}\text { Central goverment sets the rate and base of the } \\
\text { local government tax }\end{array}$ \\
\hline f & $\begin{array}{l}\text { None of the above categories a, b, c, d or e } \\
\text { applies }\end{array}$ \\
\hline
\end{tabular}

This methodology for the classification of tax levels is a very useful tool to assess local autonomy.
Although the possibility of measurement error of the share of sub-central expenditure or revenue is recognised, these measures are still used by many researchers due to the lack of alternatives. Even though the taxing power index might be recognised as a better alternative, the data on taxing power is available only for OECD countries over a limited time span. For an empirical study based on a broader sample of countries for a longer period, the share of local government revenue is still the only available data to measure fiscal decentralisation. In a recent study on the effects of fiscal decentralisation on economic growth and interregional disparity, Rodríguez-Pose, Krøijer (2009), Ezcurra, Rodriguez-Pose (2010), and RodriguezPose, Ezcurra (2011) use sub-central shares in total government expenditure and revenue as the measure of fiscal decentralisation.

Tax sharing is used in many countries as a system of allocating national tax revenues across levels of government. According to the OECD surveys on local governments' tax revenue structure (OECD 1999, 2002; Blöchliger, Petzold 2009), it is a dominant source of local tax revenue for several OECD countries. In Austria, the Czech Republic, Germany, Mexico, and Turkey, the shares of tax sharing in local tax revenue are respectively $89 \%$, $97 \%, 75 \%, 84 \%$ and $100 \%$. Besides these countries, the shares of tax sharing are also quite significant in such countries as Australia, Belgium and Spain, which are respectively $42 \%, 46 \%$ and $32 \%$.

In sum, the current definition of taxing power developed by the OECD (Blöchliger, Petzold 2009) can be modified with the concept of "tax base proportionality", which is defined as tax sharing subtracted by horizontal grants. This approach has two advantages. Firstly, it will prevent the degree of fiscal decentralisation in many federal/regional countries from becoming close to zero. Secondly, the dichotomous nature of the current definition of the OECD (Blöchliger, Petzold 2009) can be overcome by calculating the contribution of the local tax base to tax sharing revenue on a continuous basis.

But there are more indicators in scientific literature. Reviewing the relevant literature, Table 2 provide the representation of various local government revenue autonomy measures.

These indicators which could help to evaluate level of revenue autonomy, but there is not one of the best, so multicriteria methods will help to make index of revenue autonomy of local government. The next section presents the methodology of local government revenue autonomy index. 
Table 2. Indicators of local government revenue autonomy (Source: authors)

\begin{tabular}{l|l|l}
\hline \multicolumn{1}{c|}{ Measure } & \multicolumn{1}{c|}{ Definition } & \multicolumn{1}{c}{ Authors } \\
\hline $\begin{array}{l}\text { Revenue Decen- } \\
\text { tralization indi- } \\
\text { cator (RDI) }\end{array}$ & $\begin{array}{l}\text { SCG own } \\
\text { revenue/GG } \\
\text { revenue }\end{array}$ & $\begin{array}{l}\text { Eyraud, Lusinyan } \\
\text { (2011); Escolano } \\
\text { et al. } \text { (2012) }\end{array}$ \\
\hline $\begin{array}{l}\text { Revenue Au- } \\
\text { tonomy (RA) }\end{array}$ & $\begin{array}{l}\text { SCG own } \\
\text { revenue/SCG } \\
\text { revenue }\end{array}$ & $\begin{array}{l}\text { Stegarescu } \\
(2005)\end{array}$ \\
\hline $\begin{array}{l}\text { Revenue Au- } \\
\text { tonomy II (RA }\end{array}$ & $\begin{array}{l}\text { SCG own } \\
\text { revenue/SCG } \\
\text { expenditure }\end{array}$ & $\begin{array}{l}\text { Martinez- } \\
\text { Vazquez, } \\
\text { Timofeev (2009) }\end{array}$ \\
\hline $\begin{array}{l}\text { Local govern- } \\
\text { ment revenue as } \\
\text { percentage of } \\
\text { GDP }\end{array}$ & $\begin{array}{l}\text { SCG reve- } \\
\text { nue/GDP }\end{array}$ & $\begin{array}{l}\text { Word Bank } \\
(2001)\end{array}$ \\
\hline $\begin{array}{l}\text { Tax revenue } \\
\text { decentralization }\end{array}$ & $\begin{array}{l}\text { SCG tax re- } \\
\text { venue/GG } \\
\text { tax revenue }\end{array}$ & $\begin{array}{l}\text { Blochliger } \\
(2013), \text { Blochli- } \\
\text { ger, Nettley } \\
(2015)\end{array}$ \\
\hline
\end{tabular}

Note: SCG - local government; CG - central government.

\section{Methodology of local government revenue index}

Multicriteria evaluation methods have been used in Lithuania for more than 30 years. At first they were used for solving technological problems in construction. Various evaluation techniques beginning with simple (sum of places, geometric average), more accurate ones (SAW COPRAS) and finishing by the most complicated ones - TOPSIS, VIKOR, MOORA, MULTIMOORA, ELECTRE, PROMETEY, PROMETEI II and others) are used. Actually, multicriteria methods allow us to quantitatively evaluate any complicated object described by a set of criteria, and they let to combine both maximizing and minimizing criteria expressed in various dimensions into one integrated criterion. The maximizing criteria imply that, if their values are growing, the situation is getting better, while for minimizing criteria this means a worsening situation. The integration is achieved by normalization which helps to convert all the criteria values into non-dimensional, i.e. comparable quantities (Ginevičius, Podvezko 2007). Many similar assignments, involving various technical, social and other problems have been solved. The major part is devoted to deal with the construction issues, such as evaluation of construction contracts (Podvezko et al. 2010), commercial facilities construction place setting (Zavadskas et al. 2009), management of vocational training quality (Andriušaitienè et al. 2008), tax system evaluation (Bivainis, Skač- kauskienė 2009), financial system evaluation (Žvirblis, Buračas 2010), product quality evaluation (Pabedinskaite, Vitkauskas 2009), company's environmental components evaluation (Žvirblis, Zinkevičiūte 2008), enterprise enterprise marketing activities evaluation (Ginevičius et al. 2013), Lithuanian banks's financial stability and soundness evaluation (Ginevičius, Podviezko 2013), the effect of state subsidies on business evaluation (Ginevičius, Bruzgè 2013); networking of a higher education institution strategic assessment (Nugaras 2014) and other evaluations. Evaluation of local government revenue autonomy is a new object for using multicriteria evaluation methods.

Quantitative evaluation methods are based on the matrix of the criteria, describing the compared object, statistical data or experts' estimates $\mathrm{R}=\left\|\mathrm{r}_{\mathrm{ij}}\right\|$ and the criteria weights $\omega_{i}, \mathrm{i}=1, \ldots, \mathrm{m}$; $\mathrm{j}=1, \ldots, \mathrm{n}$, where $\mathrm{m}$ is the number of the criteria, $\mathrm{n}-$ the number of the objects (alternatives) compared.

Methods differ in their complexity. The most widely used method is SAW (Simple Additive Weighting). The quantitative assessment of local government revenue autonomy may also be done by applying a multi-criteria model based on the SAW (Simple Additive Weighting) method (Hwang, Yoon 1981):

SAW multicriteria evaluation method is one of the most understandable and the simpliest ones embodying indexes values and weights connection into a single evaluating size - method criterion. Revenue autonomy by SAW method can be calculate in this way:

$$
S_{j}=\sum_{i=1}^{m} \omega_{i} \tilde{r}_{i j},
$$

where: $S_{j}-$ the value of the quantitative assessment of local government revenue autonomy $\omega_{i}-$ the weight of indicator of local government revenue autonomy; $\widetilde{r}_{i j}$ - the normalized value of indicator $i$ of local government revenue autonomy. The multi-criteria assessment SAW method requires the nature of change of all indicators to be the same, i.e. all of them need to be maximizing or minimizing.

We need to determine of local government revenue autonony of a country, therefore we should perform normalization employing the ESP method.

In this case, the normalization of the initial data can be performed by the formula (Ginevičius, Podvezko 2006; Ginevičius et al. 2015): 


$$
\overline{r_{i j}}=\frac{r_{i j}}{\max _{j} r_{i j}}
$$

where $r_{i j}$ - the normalized value of indicator $i$; $\max$ $r_{i j}-$ the highest value of indicator $i$ (obtained from statistical data or established through expert assessment).

Indexes weights can be determined in two main ways: direct and indirect. The first way is suitable when the number of evaluated indexes is not big - till some (Ginevičius 2007). Experts determine the weights of indexes in parts of a unit at once. This technique is very simple, understandable and convenient to apply. When the number of evaluation indexes increases, it becomes problematic to apply it. The reason is that it is harder for an expert to determine the correlated relations of indexes weights from the point of view of an examined phenomenon. At the same time the incompatibility of opinions grows which often exceeds allowable limits. The best known one is T. Saaty hierarchy analysis method (Saaty 1980; Ferreira 2013; Aqhdaie et al. 2013). In this case the experts compare only two indexes, but not all at once. The other one which is less widespread for the present, named FARE method, is also grounded on reciprocity of indexes (Ginevičius 2011). On the basis of minimal initial information about the main index influence on other system indexes, the interrelations and strength of all the rest indexes are determined by applying an analytical technique. It allows to form completely coordinated matrix of indexes interactions and to calculate the weights of a larger number of indexes considerably more accurately.

The weight values can be used in further multicriteria evaluation, provided that experts judgments are consistent (in concordance). The concordance level can be determined by Kendall's concordance coefficient W (Kendall 1970):

$$
W=\frac{12 S}{r^{2} m\left(m^{2}-1\right)-r \sum_{j=1}^{r} T_{j}}
$$

where $r$ is the number of experts, $m-$ the number of the criteria considered.

In fact, the concordance degree of experts' estimates is determined by the value $\chi^{2}$ rather than the concordance coefficient W (Kendall 1970):

$$
\chi^{2}=W r(m-1)=\frac{12 S}{r m(m+1)}
$$

It has been shown (Kendall 1970) that if the value of $\chi^{2}$ calculated by formula (4) is larger than its critical value $2 \chi^{2}$ kr taken from the distribution table of $\chi^{2}$ with $v=m-1$ degree of freedom and the significance level $\alpha$ chosen to be close to zero, then the statistical hypothesis about expert estimates' consistency is adopted.

\section{Local government revenue autonomy index in selected Europe countries}

The main purpose of this section is to calculate the local government revenue autonomy index for a range of developing and developed Europe economies to facilitate subsequent investigations of the relationship.

For research was selected these Europe countries:

- Developed: United Kingdom, Denmark, Netherlands, France, Finland, Sweden, Luxemnourg.

- Developing: Estonia, Greek, Poland, Lithuania, Slovakia, Slovenia, Hungary.

Data was taken from Word Bank, OECD, Eurostat and calculated (Table 3 ).

Table 3. Europe Countries indicators (Source: authors)

\begin{tabular}{l|c|c|c|c|c|c}
\hline Indicators & $\mathrm{I}_{1}$ & $\mathrm{I}_{2}$ & $\mathrm{I}_{3}$ & $\mathrm{I}_{4}$ & $\mathrm{I}_{5}$ & $\mathrm{I}_{6}$ \\
\hline
\end{tabular}

DEVELOPED EUROPE COUNTRIES

\begin{tabular}{l|l|l|l|l|l|l|}
\hline United Kingdom & 0.91 & 0.46 & 0.45 & 0.25 & 0.11 & 0.30 \\
\hline Denmark & 1.00 & 1.00 & 0.59 & 0.60 & 0.93 & 1.00 \\
\hline Netherlands & 0.98 & 0.49 & 0.99 & 0.18 & 0.11 & 0.37 \\
\hline France & 0.71 & 0.34 & 0.96 & 0.84 & 0.42 & 0.32 \\
\hline Finland & 0.94 & 0.67 & 0.99 & 0.78 & 0.77 & 0.63 \\
\hline Sweden & 1.00 & 0.80 & 0.98 & 0.93 & 1.00 & 0.68 \\
\hline Luxembourg & 0.91 & 0.68 & 0.42 & 0.09 & 0.14 & 0.68 \\
\hline
\end{tabular}


Continued Table 3

\begin{tabular}{l|c|c|c|c|c|c|c}
\hline Indicators & $\mathrm{I}_{1}$ & $\mathrm{I}_{2}$ & $\mathrm{I}_{3}$ & $\mathrm{I}_{4}$ & \multicolumn{2}{|c}{$\mathrm{I}_{5}$} & $\mathrm{I}_{6}$ \\
\begin{tabular}{l|l|l|l|l} 
Countries \\
DEVELOPING EUROPE COUNTRIES
\end{tabular} & 0.30 & 0.38 & 0.85 & 0.07 & 0.02 & 0.25 \\
\hline Estonia & 0.69 & 0.13 & 0.52 & 0.42 & 0.06 & 0.10 \\
\hline Greek & 0.47 & 0.55 & 0.61 & 0.56 & 0.32 & 0.36 \\
\hline Poland & 0.42 & 0.38 & 0.16 & 0.10 & 0.03 & 0.22 \\
\hline Lithuania & 0.92 & 0.27 & 0.43 & 0.19 & 0.06 & 0.18 \\
\hline Slovakia & 0.25 & 0.35 & 0.81 & 0.69 & 0.28 & 0.26 \\
\hline Slovenia & 0.78 & 0.31 & 0.55 & 0.41 & 0.16 & 0.25 \\
\hline
\end{tabular}

Using the calculated structure of tax revenue (OECD) we built an index of tax autonomy for the Europe countries. The index's values indicate the degree of local and regional governments control over their own tax revenues, ranging from 1 till 0 . In this setting, we multiplied the shares of each taxes that fall in the (a) category with 1.00 , (b) with 0.8 , then, categories (c) to (e) with $0.7,0.6$, $0.5,0.3,0.2,0$, and, respectively, 0.1 .

It is expected index of tax autonomy for "developed" and "developing" nations will be different. The degree of tax autonomy of local government in developed countries generally higher. Such developed countries like United Kingdom, Denmark, Netherlands, Finland, Sweden and Luxembourg local government tax autonomy index is near 1 , it is mean that local government has a big power to control own tax revenue. In contrast to the situation in the developing countries, where Estonia, Poland, Lithuania ans Slovenia has tax autonomy index less then 0.5 , which mean that local government has not a big power to control own tax revenue (see Fig. 1).

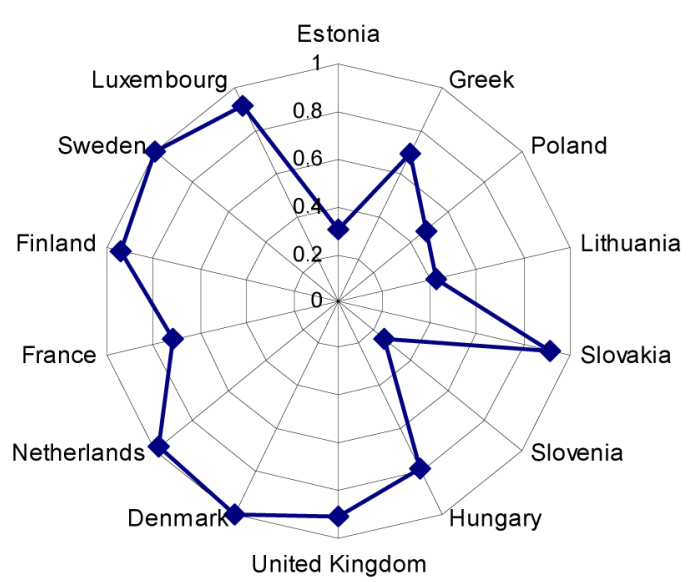

Fig. 1. Tax autonomy index of local government in Europe countries (Source: authors)
In second step was calculated weights for local government revenue autonomy index. The weights of local government revenue autonomy indicators of the coutries were determined by interviewing experts. A great number of weight determination methods are available. They range from the rating of criteria and direct evaluation to criteria pairwise comparison AHP (Analytic Hierarchy Process) developed by Saaty (Saaty 1980; Ginevičius et al. 2004). In the present investigation, a direct method of weight determination was used, when each expert assesses the weight of a particular criterion, expressing it in per cent, so that the sum of criteria weights is equal to 1 (or 100 percent).

The estimates of 6 criteria (Table 3 ) provided by 10 expert from different countries (such like Austria, Italy, Rumunia, Slovenia and other, see Table 4).

Table 4. Experts by countries (Source: authors)

\begin{tabular}{l|l|l|l|l|l|l|l|l|l|l|l}
\hline Expert & & & & & & & & & & & \\
Country & 1 & 2 & & 3 & 4 & 5 & 6 & 7 & 8 & 9 & 10 \\
\hline Austria & & & & & & & & & & + & \\
\hline Italy & + & & & & & & & & & & \\
\hline Lithuania & & & & & + & & & & + & & + \\
\hline Portugal & & & & & & & & + & & & \\
\hline Rumunia & & + & & + & & & & & & & \\
\hline Slovenia & & & & & & + & & & & & \\
\hline Turkey & & & & & & & + & & & & \\
\hline
\end{tabular}

The concordance coefficient $\mathrm{W}=0.74$ was calculated by formula (3). The value of $\chi^{2}=33.25$ calculated by formula (4) exceeds the critical value $\chi^{2} \mathrm{kr}=11.07$ with the significance level $\alpha=0.05$. It shows that experts' judgements are consistent and the criteria weights, calculated based on expert estimates can be used in multicriteria evaluation. 
In the last step (formula 1) was calculated index of local government revenue autonomy in Europe countries (see Fig. 2).

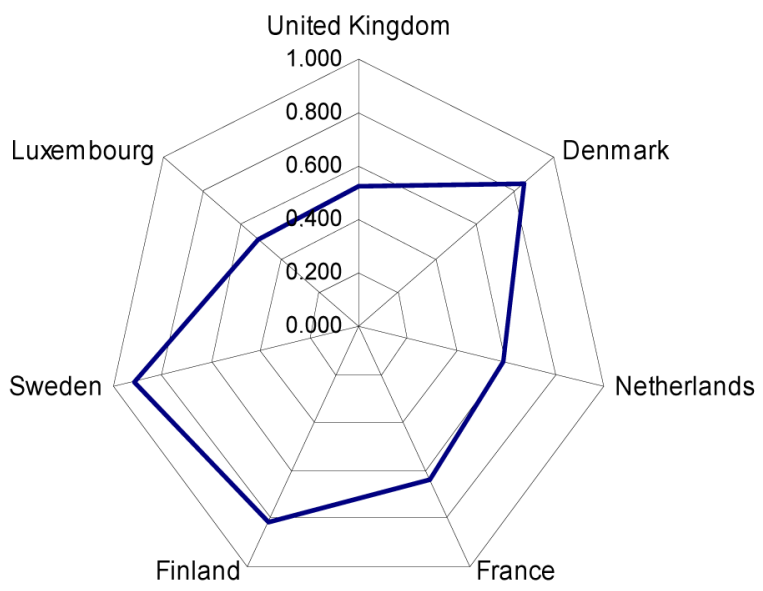

Fig. 2. Revenue autonomy index of local government in developed Europe countries (Source: authors)

Calculation results are shown in Figure 1 and 2 for developed and developing Europe countries. As seen in Figure 1, revenue autonomy index range from as high as 0.85 in Sweden and less 0.52 in Luxenbourg. In contrast to the situation in the developing countries, where local government revenue autonomy index is less then 0.5 (see Fig. 3).

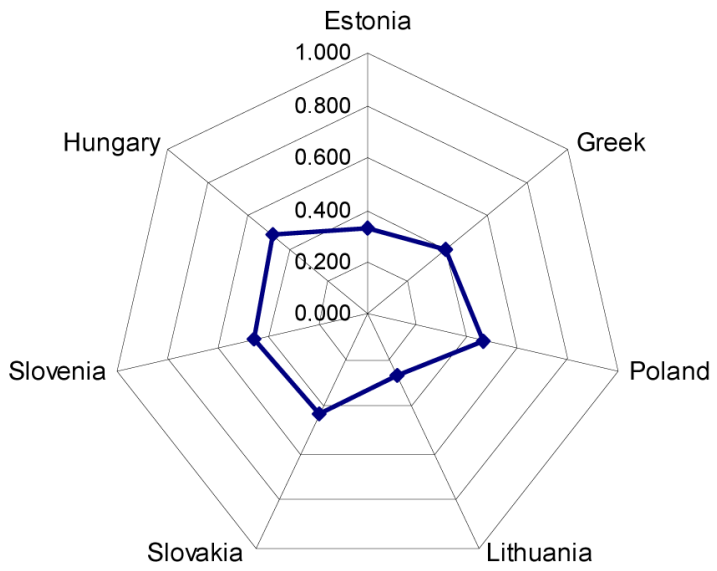

Fig. 3. Revenue autonomy index of local government in developing Europe countries (source: authors)

The highest index of revenue autonomy has Hangary (0.48) and lowest in Lithuania, only 0.26. Local government revenue autonomy index in Lithuania is the lowest among 14 Europe countries.

\section{Conclusions}

Fiscal decentralisation is influenced by many countries specific factors such as politics, history and culture. Therefore the measurement of fiscal decentralisation with consistent criteria across countries is a challenging task.

Multicriteria evaluation methods have been used in Lithuania for more than 30 years. At first they were used for solving technological problems in construction. Their universal nature allowed to start applying them later in analysing socioeconomic systems, especially in quantative evaluating of the processes which have such nature and for evaluation of expressions position. Evaluation of local government revenue autonomy is a new object for using multicriteria evaluation methods.

The degree of tax autonomy of local government in developed countries is higher then in developing countries. This results show that local government in developed countries (such like Swedan, Denmark and other) has a big power to control own tax revenue then in developing countries (Estonia, Poland and other).

The degree of revenue autonomy of local government is higher in developed countries then in developing countries. Revenue autonomy index in developed countries range from 0.85 till 0.52 ( 0.85 in Sweden and less 0.52 in Luxenbourg). Local government revenue autonomy index in Lithuania is the lowest among 14 Europe countries.

\section{References}

Andriušaitienè, D.; Ginevičienè, B. V.; Šileika, A. 2008. Daugiakriterinis profesinio mokymo kokybès valdymo vertinimo modelis [Multicriteria method for evaluating quality management of professional training], Verslas: teorija ir praktika 9(2): 88-96 (in Lithuanian).

Aqhdaie, M. H.; Zoltani, S. M.; Zavadskas, E. K. 2013. Market segment evaluation and selection based on application of fuzzy AHP and COPRAS- G methods, Journal of Business Economics and Management 14(1): 213-233. http://dx.doi.org/10.3846/16111699.2012.721392

Beer-Toth, K. 2009. Local financial autonomy in theory and practice: the impact of fiscal decentralization in Hunggary': Doctor Economics and Social Science thesis. University of Fribourgh, Fribourgh.

Bivainis, J.; Skačkauskienè, I. 2009. Kompleksinio mokesčiu sistemos vertinimo rodiklių sistema [A system of indicators for the complex evaluation of the tax system], Verslas: teorija ir praktika 10(4): 298-307 (in Lithuanian). 
Blankart, Ch. 2000. The process of government centralization: a constitutional view, Constitutional Political Economy 11(1): 27-39.

http://dx.doi.org/10.1023/A:1009018032437

Blöchliger H.; Petzold, O. 2009. Finding the dividing line between tax sharing and grants a statistical investigation. OECD Working Papers on Fiscal Federalism. OECD Publishing.

Blochliger, H. 2013. Decentralization and economic growth - part 1: how fiscal federalism affects long-term development. OECD Working Papers on Fiscal Federalism, 14. OECD Pusblishing.

Blochliger, H.; Nettley, M. 2015. Sub-central tax autonomy: 2011 update. OECD Working Papers on Fiscal Federalism, 20. OECD Publishing.

Boschmann, N. 2009. Fiscal decentralization and opti ons for donor harmonisation. bonn: development partners working group on local governance and decentralization [online], [cited 10 February 2016]. Available from Internet:

http://www.delog.org/cms/upload/pdf/Fiscal_Dece ntralisation.pdf

Davey, K. 2003. Fiscal decentralization [online], [cited 15 January 2016]. Available from Internet: http://unpan1.un.org/intradoc/groups/public/docum ents/untc/unpan017650.pdf

Davoodi, H.; Zou, H. 1998. Fiscal decentralization and economic growth: a cross-country study, Journal of Urban Economics 43: 244-257. http://dx.doi.org/10.1006/juec.1997.2042

Ebel, R. D.; Yilmaz, S. 2003 On the measurement and impact of fiscal decentralization, in J. Alm. Developing and transition countries: essays in honour of Richard M. Bird. Cheltenham: Edward Elgar Press, 101-120.

Escolano, J.; Eyraud, L.; Moreno Badia, M.; Sarnes, J.; Tuladhar, A. 2012. Fiscal performance, institutional design and decentralization in European Union countries, Working paper 45, IMF.

Eyraud, L.; Lusinyan, L. 2011. Decentralizing spending more than revenue: does it hurt fiscal performance? Working paper 11/226, IMF.

Ezcurra, R.; Rodríguez-Pose, A. 2010. Is fiscal decentralization harmful for economic growth? Evidence from the OECD countries, SERC Discussion Papers.

Ferreira, A. F. 2013. Measuring trade-ofts among criteria in a balanced score card frame work: possible contribuctions from the multiple criteria decision analysis research field, Journal of Business Economics and Management 14(3): 433-447. http://dx.doi.org/10.3846/16111699.2011.631744

Word Bank. 2001. Fiscal Decentralization Indicators [online], [cited 10 January 2016]. Available from Internet: http://www1.worldbank.org/publicsector/ decentralization/webfiscal.pdf
Fossati, A.; Panella, G. 1999. Fiscal federalism in the European Union. Routledge studies in the Europe Economy. Routledge.

Ginevičius, R. 2007. Hierarchical structuring of processes and phenomena, Business: Theory and Practice 8(1): 14-18.

Ginevičius, R. 2011. A new determining methot for the criteria weights in multicriteria evaluation, International Journal of Information Technology \& Decision Making 10(6): 1067-1095. http://dx.doi.org/10.1142/S0219622011004713

Ginevičius, R.; Bruzgè, Š. 2013. Evaluation of the effect of state subsidies on business, Business, Management and Education 11(1): 50-76. http://dx.doi.org/10.3846/bme.2013.04

Ginevičius, R.; Gedvilaitè, D.; Bruzgè, Š. 2015. Assessment of a country's regional economic development on the basis of Estimation of a Single Process (ESP) method, Entrepreneurial Business and Economics Review (EBER) 3(2): 141-153. http://dx.doi.org/10.15678/EBER.2015.030210

Ginevičius, R.; Podvezko, V. 2006. Assessing the Financial state of constructiom enerprises, Ūkio technologinis ir ekonominis vystymas 12(3): 188194.

Ginevičius, R.; Podvezko, V. 2007. Some problems of evaluating multicriteria decision methods, International Journal of Manegementt and Decision Making 8(5/6): 527-539. http://dx.doi.org/10.1504/IJMDM.2007.013415

Ginevičius, R.; Podvezko, V.; Andruškevičius, A. 2004. Determining of technological effectiveness of building systems by AHP method, Technological and Economic Development of Economy 10(4): 135-141.

Ginevičius, R.; Podviezko, A. 2013. The evaluation of financial stability and soundness of Lithuanian banks, Ekonomska istrazivanja - Economic Research 26(2): 191-208.

Ginevičius, R.; Povezko, V.; Ginevičius, A. 2013. Quantitative evaluation of enterprise marketing activities, Journal of Business Economics and Management 14(1): 200-212. http://dx.doi.org/10.3846/16111699.2012.731143

Hwang, C. L.; Yoon, K. 1981. Multiple attribute decision making-methods and applications. A state of the art survey. Berlin, Heidelberg, New York: Springer Verlag.

Kendall, M. 1970. Rank correlation methods. London: Griffin.

Martinez-Vazquez, J.; Timofeev, A. 2009. Decentralization measures revisited. International Studies Program Working Paper 09-13.

Nugaras, J. 2014. Assessment of networking of higher education institution: doctoral dissertation. Vilnius: Technika. $126 \mathrm{p}$. 
Oates, W. E. 1996. Taxation in a federal system: the tax-assignment problem, Public Economic Review 1: $35-60$.

Oates, W. E. 2005. toward a second-generation theory of fiscal federalism, International Tax and Public Finance 12(4): 349-373. http://dx.doi.org/10.1007/s10797-005-1619-9

Oates, W. E. 2008. on the evolution of fiscal federalism: theory and institutions, National Tax Journal 61(2): 313-334.

http://dx.doi.org/10.17310/ntj.2008.2.08

OECD. 1999. Taxing powers of state and local government. Tax Policy Studies, 1. OECD Publishing.

OECD. 2002. Fiscal design surveys across levels of government. OECD, Paris.

Pabedinskaitè, A.; Vitkauskas, R. 2009. Daugiakriterinis produkto kokybès vertinimas [Multicriteria evaluation of product quality], Verslas: teorija ir praktika 10(3): 214-222 (in Lithuanian).

Podvezko, V.; Mitkus, S.; Trinkūnienè, E. 2010. Complex evaluation of contracts for construction, Journal of Civil Engineering and Management: International Research and Achievements 16(2): 287297. http://dx.doi.org/10.3846/jcem.2010.33

Rodríguez-Pose, A.; Ezcurra, R. 2011. Is fiscal decentralisation harmful for economic growth? Evidence from the OECD countries, Journal of Economic Geography 11(4): 619-643.

http://dx.doi.org/10.1093/jeg/lbq025

Rodríguez-Pose, A.; Krøijer, A. 2009. Fiscal decentralisation and economic growth in Central and Eastern Europe. LEQS Paper no. 12. London School of Economics and Political Science.
Saaty, T. 1980. The analytical hierarchy process: Planning, priority setting, resource allocation. NY: McGraw-Hill.

Stegarescu, D. 2005. Public sector decentralization: Measurement concepts and recent international trends, Fiscal Studies 26(3): 301-333. http://dx.doi.org/10.1111/j.1475-5890.2005. 00014.x

Tiebout, C. 1956. A pure theory of local expenditures, Journal of Political Economy 64: 416-424. http://dx.doi.org/10.1086/257839

Zavadskas, E. K.; Ustinovičius, L.; Stasiulionis, A. 2009. Multicriteria valuation of commercial construction projects for investment purposes, Journal of Civil Engineering and Management 10(2): 151166. http://dx.doi.org/10.1080/13923730.2004.9636299

Žvirblis, A.; Zinkevičiūtè, V. 2008. Imonès aplinkos komponentu daugiakriterio kiekybinio vertinimo principai ir modeliai [Multicriteria quantitative evaluation principles and models of company environmental components], Verslo ir teisés aktualijos 1: 183-191 (in Lithuanian).

Žvirblis, A; Buračas, A. 2010. The consolidated measurement of the financial markets development: the case of transitional economies, Technological And Economic Development of Economy 16(2): 266279. http://dx.doi.org/10.3846/tede.2010.17 